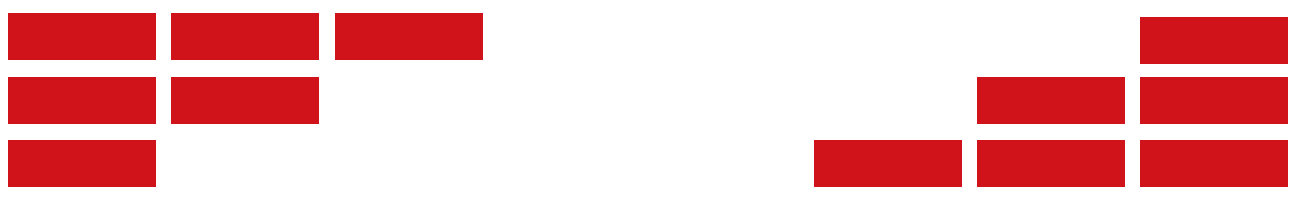

\title{
Why do mexicans report so little crime? The determinants of crime reporting in Mexico
}

\author{
¿Por qué los mexicanos denunciamos tan poco? \\ Los determinantes de la denuncia \\ de delitos en méxico
}

Constantino Carreto Romero

El Colegio de México, Center for Economic Studies ccarreto@colmex.mx

Aurora A. Ramírez-Álvarez

El Colegio de México, Center for Economic Studies aurora.ramirez@colmex.mx 
Why do mexicans report so little crime? The determinants of crime reporting in Mexico

\section{Abstract}

We analyze the factors that explain a victim's decision to report burglary, public theft, extortion, and fraud to the public prosecutor's office in Mexico. Using a probit model and combining survey and census data, we examine how reporting is explained by the sociodemographic characteristics of the victim, variables describing the incident, the victim's perceptions regarding police and public safety, and regional characteristics regarding public safety and government. Results show that variables describing the incident are the most consistent predictors across all crime types, while some sociodemographic characteristics are relevant for specific types. Our results for victims' perceptions and community characteristics show that increasing perception of police corruption reduces burglary reporting and that a greater generalized perception of police corruption reduces fraud reporting. These results suggest that there is room for increasing crime reporting by policies oriented to reduce police corruption and improve the population's perception of the police.

Keywords: criminal justice; crime reporting; criminal records; crime victims; crime patterns; Mexico.

\section{JEL Classification: K42}

\section{Resumen}

Analizamos los factores que explican la decisión de una víctima de denunciar ante el Ministerio Público, el robo a domicilios, robo en la vía pública, extorsión y fraude. Utilizando un modelo probit y combinando datos de encuestas y censos, examinamos cómo la denuncia se explica por las características sociodemográficas de la víctima, las variables que describen el incidente, las percepciones de la víctima con respecto a la policía y la seguridad pública; así como las características regionales con respecto a la seguridad pública y el gobierno. Los resultados muestran que las variables que describen el incidente son los predictores más consistentes en todos los tipos de delitos. Nuestros resultados sobre las percepciones de las víctimas y las características regionales muestran que una mayor percepción de corrupción policial está asociada a una reducción de la denuncia de robo a casa habitación y que una percepción generalizada de corrupción policial está asociada a una reducción de la denuncia de fraude. Estos resultados sugieren que hay espacio para incrementar la denuncia de delitos mediante la implementación de políticas orientadas a reducir la corrupción policial y mejorar la percepción de la población sobre la policía.

Palabras clave: justicia penal; denuncia de delitos; estadísticas criminales; víctimas de delitos; patrones de delincuencia; México.

Fecha de recepción: 4 de octubre de 2021 . Fecha de aceptación: 6 de diciembre de 2021.

Fecha de publicación: 17 de enero de 2022. 


\section{Introduction}

In recent years, Mexico has become one of the most dangerous countries, not just in Latin America but in the world. ${ }^{1}$ From 2005 to 2017, there was a 223 percent increase in the number of homicides, while other crimes, including extortion, kidnapping, robbery, murder, and threats, have spiked as well (Beittel, 2015; Robles et al., 2013; Villanueva, 2019). Moreover, most of these crimes are not reported. For example, according to the National Survey of Crime Victims and Perceptions of Public Safety (ENVIPE, 2019), 97.9 percent of extortions and 91.2 percent of kidnappings were not reported in 2018. Figure 1 shows the disparity between official records and victim survey data for burglaries. Registers and survey data of burglaries differ in both trend and magnitude, and the official registers consistently underreport their incidence. This underreporting is alarming, as it implies that most crimes in Mexico are not investigated or punished. It also affects the design of crime mitigation policies, since official records are the first-line source for the analysis of crime trends. ${ }^{2}$

If we wish to foster higher rates of crime reporting, it is necessary to understand the factors that explain people's behavior in deciding whether to report crimes or not. Several factors make this analysis difficult. First, victim surveys - the standard type of data used in this type of analysis — suffer from a gap in time between the occurrence of the crime and the interview. Victims may suffer from recall bias, and they may not accurately describe the characteristics of the crime. The time gap also means that we cannot know the victim's precise perceptions about the police or public safety at the time of a crime that influenced the decision about whether to report it. Second, surveys do not necessarily include information about whether the victim reported the crime to the police. In Mexico, crime victims may call the police, but the formal report of a crime is made not with

1 Mexico has the 8th highest murder rate in Latin America and the 25th highest in the world (Pariona, 2018).

2 For example, based on official records of extortion, in 2019 the federal government decided to compile a database of phone numbers used by extortionists. The first step consisted of sending pollsters to different parts of the country. Taking into account the information provided by respondents, they collected phone numbers and bank account numbers, as well as other data. Nonetheless, note that the planned geographic distribution of pollsters might have been affected by the bias in extortion records, leading to an inaccurate coverage of regions in the country according to their real extortion levels (Lastiri, 2019). 
Why do mexicans report so little crime? The determinants of crime reporting in Mexico

the police but with the public prosecutor's office (the Ministerio Público) ${ }^{3}$. Third, since being the victim of a crime is not random, direct estimations of the propensity to report crime might be biased if we do not consider the processes that condition it.

Figure 1. Trends in total and reported burglaries

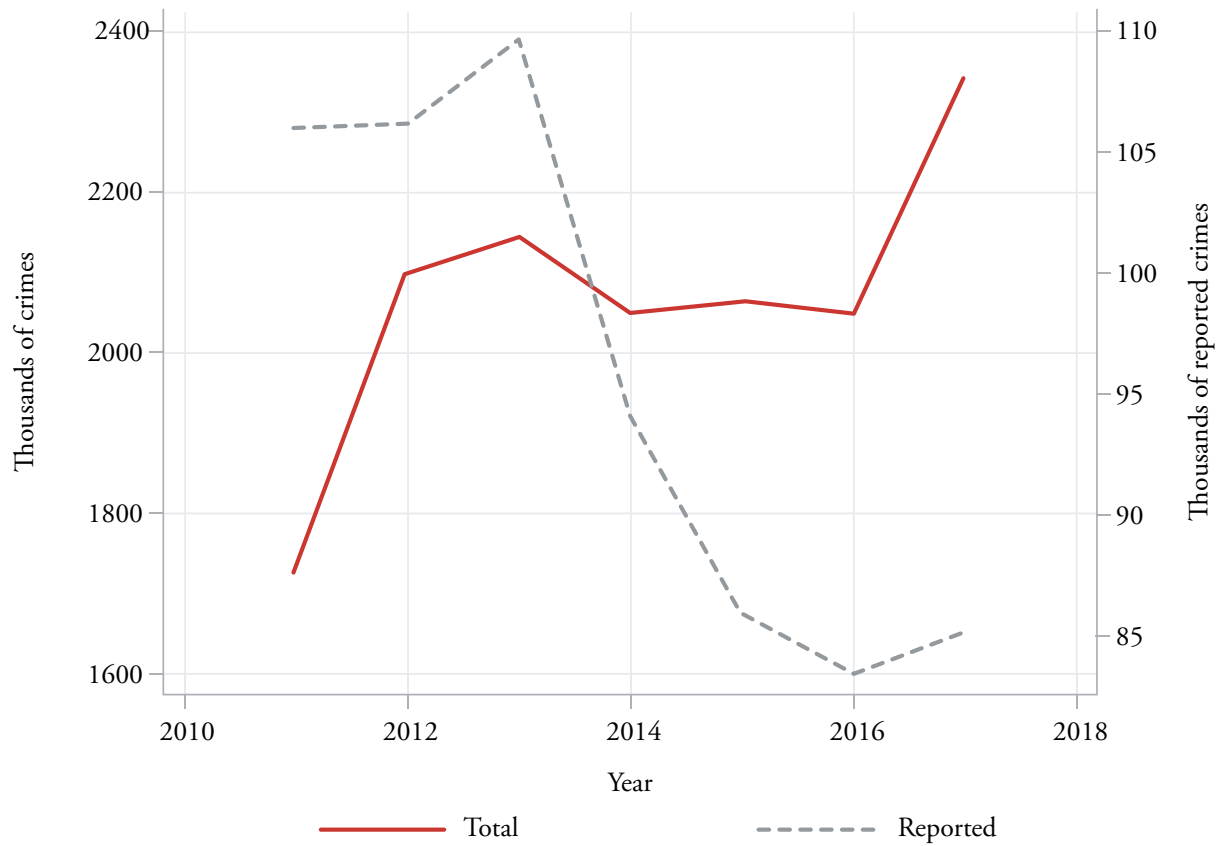

Source: Own elaboration based on ENVIPE and STSNSP data.

Note: Total burglaries are estimations based on ENvipe 2012-2018. For this figure, reported crime data comes from the Executive Secretary of the National System of Public Safety (STSNSP) and represents the occurrence of alleged crimes recorded in investigation files initiated in the public prosecutor's office.

In this paper, we study the determinants of crime reporting in Mexico: the main objective is to describe the factors that explain the decision by victims of crime to report it. We cluster explanatory variables into individual and aggregated categories to distinguish which individual or community-level features have a greater

3 Our analysis defines reporting a crime as making a formal complaint with the Ministerio Público. 
influence on this decision. The individual variables are based on previous studies ${ }^{4}$ (Greenberg \& Beach, 2004; Kääriäinen \& Siren, 2011; MacDonald, 2001; Torrente et al., 2017; Zhang et al., 2007), and distinguish between sociodemographic factors, the characteristics of the crime, and variables related to the victim's perception. We perform our analysis separately for four types of crime: burglary, public theft (on the street or in public transportation), extortion, and fraud. Our data sources include victim surveys, government quality surveys, and government censuses for the years 2011,2013, 2015, and 2017. We estimate the probability of reporting a crime by implementing a probit model. Since reporting a crime might depend on the interaction of the probability of becoming a victim and the probability of reporting a crime, we also perform a bivariate probit and confirm that our results are robust to this specification.

Our main findings show that the factors that explain crime reporting vary across all types of crime, but the group of variables that describe the details of the crime is the most consistent in explaining it. For instance, an increasing estimated economic loss due to the crime, explains a greater propensity to report, no matter the crime type under analysis. However, the explanatory power of the perceptions and community characteristics vary significantly depending on the crime type. Moreover, we show that individual perceptions about police corruption influence crime reporting: a victim's perception that municipal police are corrupt decreases the probability of reporting a burglary, and the generalized perception of police corruption decreases the reporting of fraud.

Our work contributes to the literature that investigates the determinants of crime reporting (Allen, 2007; Benavente \& Cortés, 2006; Greenberg \& Beach, 2004; Kääriäinen \& Siren, 2011; MacDonald, 2001; Torrente et al., 2017; Zhang et al., 2007). Our contribution to the literature is two-fold. First, to the best of our knowledge, this is the first study on crime reporting for a developing and highly violent country. Second, we consider a series of variables that reflect perceptions about institutions of public safety that might be related to the decision to report a crime. The influence of some of these factors, such as perceptions about police corruption and government effectiveness, to the best of our knowledge, has not previously been analyzed.

4 Since there is no economic theory to explain crime reporting, we rely on previous studies on the topic, some of which build upon criminological theories to identify the factors that might influence it. 
The rest of this article is organized as follows. Section 2 surveys the literature. Section 3 describes the data and methods, and Section 4 presents and discusses the results. Finally, Section 5 offers some conclusions.

\section{Related Literature}

The factors that determine the decision to report a crime have been the object of extensive study by criminologists. Most of these studies focus on the incident and on the psychological characteristics that lead a victim to report a crime (Goudriaan \& Nieuwbeerta, 2007; Guzy \& Hirtenlehner, 2015; Sidebottom, 2014; Tarling \& Morris, 2010; Yun \& Mueller, 2011). However, there are few studies that also analyze sociodemographic or community characteristics, or the perceptions of crime victims.

A few studies focus on analyzing individual or neighborhood characteristics to explain crime reporting. Zhang et al. (2007) explore three categories of variables (victim-specific, incident-specific, and neighborhood-specific) in China. They find that the seriousness of an offense (measured through various incidentspecific variables) has an important effect on the reporting of robbery/assault and household burglary, but almost no individual, household, or neighborhoodspecific variables show any significant relationship. Allen (2007) focuses on the determinants of reporting a rape to the police in the us and the extent to which the availability of social support and evidentiary factors influence the decision to report the crime; he uses a multinomial logit model to examine victims' specific reasons for not reporting it. Goudriaan and Nieuwbeerta (2007) carry out an experiment in the Netherlands, where they expose a group of young people to descriptions of violent incidents and then test their willingness to report the crimes to the police. They find a lesser desire to report the crime when it takes place within an organization and when the offender is well known. Kääriäinen (2010) examines the effect of generalized trust and trust in the police on the willingness to report violent and property crimes in Finland, and finds that trust in the police does not appear to increase the likelihood of reporting a crime. The seriousness of the crime and, in particular, the relationship between the victim and the perpetrator do have a significant impact on the willingness to report. MacDonald (2001) uses crime surveys in the uK and analyzes the reporting of crimes with a bivariate probit model. He finds little evidence to relate reporting to individual criminality, 
but some association with perceptions about police performance. An important finding is that unemployed individuals are less likely to report a crime, which implies a relationship between the reporting rate and the economic cycles.

Other studies analyze the reporting of crimes with attention not just to neighborhood or victim characteristics, but also to a variety of features at a more aggregated level. Benavente and Cortés (2006) use a bivariate probit model to study the determinants of being a victim and reporting a crime in Chile. They find that higher educational level, age, and income, as well as the victim being male, imply a higher probability that a crime will be reported, but that police presence is not relevant. Greenberg and Beach (2004) study the reporting of crimes for three categories of variables: those related to a cost-benefit analysis of reporting the crime, those related to the victim's affective, emotional response to the crime, and those related to the social influence of advice the victim receives. Based on a sample of computer-assisted interviews, they find that of the three processes, social influence was the best predictor of whether a crime would be reported. Analysis of the affect-driven process showed that reporting was primarily a function of the level of fear rather than anger or generalized arousal upon discovering the crime.

Torrente, Gallo, and Oltra (2017) identify four categories of variables that explain crime reporting: those related directly to the type of incident, those related to victim perceptions and psychological effects, those related to institutional variables, and those related to community characteristics. Using a logit model, they test the explanatory power of each of these categories for a sample of individuals from different European countries. They find that the explanations of crime reporting rates are divided into two well-defined geographic areas: in north-central Europe, they are explained better by the type of incident and the psychology of the victim, whereas in southeastern Europe, they are explained more by sociodemographic variables and social inequality. In Eastern European countries, institutional variables are also important.

To obtain more specific results, we analyze crime reporting separately for four types of offenses: burglary, public theft (theft on the street or in public transportation), fraud, ${ }^{5}$ and extortion. ${ }^{6}$

5 Defined here as fraudulent use of a checkbook, bank card, or account number to make purchases or withdraw money from an account (bank fraud), payment with counterfeit currency, or consumer fraud.

6 Defined here as a threat demanding money, goods, an action, or cessation of an action (in the case of extortion), or a threat to cause harm to a person, their family, or property, or abusive treatment or physical injury. 
We implement a similar classification of explanatory variables as in Torrente, Gallo, and Oltra (2017) to capture most of the variation in the decision about whether to report a crime. The evaluation of specific variables to explain each crime type will thus rely strongly on those included in previous studies. We capture not just individual characteristics, but also those of the community that might influence a victim's decision to report a crime. That is why, following studies such as Benavente and Cortés (2006) and Torrente, Gallo, and Oltra (2017), we include state-level characteristics such as police presence, which might affect the decision. We include aggregated variables similar to the perceptions on the individual level, to see the different effects of individual and community perceptions on the decision to report a crime.

\section{Empirical Strategy}

\subsection{Data}

To analyze the determinants of crime reporting, we use victim surveys as our primary source of information. We take crimes as the unit of analysis. An individual might have been the victim of more than one crime in a year and would therefore appear more than once in that year in our dataset. The final dataset is thus a pooled cross-section of crimes for the years 2011, 2013, 2015, and 2017. Our binary reporting variable, sociodemographic characteristics, perceptions, and incident factors come from the annual National Survey of Crime Victims and Perceptions of Public Safety (ENVIPE); we take data from every second year for the period 2012-2018. The survey includes information on the characteristics of the crimes that respondents were victims of during the previous year, their socioeconomic profile, and their perceptions regarding topics such as corruption, security, and trust in law enforcement authorities. There is a one-year gap between the characteristics of the crime and the respondents' attitudes. Strictly speaking, the years of the offenses should be 2011,2013,2015, and 2017, and the perceptions and sociodemographic characteristics recorded are up to a year later. However, for purposes of analysis, we assume that the perceptions and sociodemographic characteristics reflect those of the previous year. Our state-level data on perceptions about corruption and government efficiency come from the National Survey on Government Quality and Impact (ENCIG), conducted in 2011, 2013, 2015, and 2017. We also add a measure of police presence, as in Benavente and Cortés 
(2006), to control for the average availability of police, given that greater access to police could imply a higher probability of reporting a crime ${ }^{7}$. These data come from the National Census of State Governments, Public Safety, and Penitentiary Systems (CNGSPSPE).

Most studies on crime reporting agree that the characteristics of the incident are the most important factors, regardless of the type of crime under analysis (MacDonald, 2001; Zhang et al., 2007). ${ }^{8}$ Individual and community characteristics are less robust predictors of reporting, and these variables usually vary from study to study. Guided by previous studies and taking into account the limitations of our data, we describe the explanatory variables for each type of crime as follows. For all types, we include the individual characteristics of gender, age, employment type (as a proxy for labor income), ${ }^{9}$ unemployment, and years of education; the incident-specific variable of the estimated value of property lost (taking the logarithm); the perceptions of trust in law enforcement authorities, concerns about crime in the area ("believing the neighborhood is safe"), belief that the police are corrupt, and beliefs about the efficacy of the police ("How good is the police in controlling crime in your area?"); and the community characteristics of police presence, belief in police corruption, and belief in the efficacy of governmental authorities. For burglaries, we include a dummy incident variable that indicates whether the victim was present when the crime occurred, ${ }^{10}$

7 We measure police presence at the state level as the number of policemen per 100 thousand inhabitants. Records about number of policemen at the municipality level are not available, which would be a more appropriate granularity. Nonetheless, it is likely police presence in the state approximates police presence in most of its municipalities.

8 Variables describing the incident include the logarithm of the estimated value of property lost, the presence of a weapon, and the relationship of the victim to the offender.

9 Employment type includes the categories unpaid worker, day laborer, employee, self-employed, and employer. We assume that labor income is generally increasing in this order.

${ }_{10}$ Burglaries are included in the analysis whether the victim was present or not, but variables such as whether the victim was injured, the perpetrator was known, whether a weapon was present during the crime, and the social influence variable of whether the victim was accompanied when the crime occurred were not included, since this would mean analyzing only burglaries where the victim was present. This type of burglary represents only 8.1 percent of the burglary sample. 
Why do mexicans report so little crime? The determinants of crime reporting in Mexico

\section{Table 1. Variable descriptions}

Variable

Female

Age

Day laborer

Employee

Self-employed

Employer

Unemployed

Years of education

Estimated lost value

Weapon present

Unknown perpetrator(s)

Victim accompanied

Present when crime the victim was present when the crime happened occurred

Trust municipal police

Believe neighborhood safe

Believe municipal police corrupt

Municipal police performance

\section{Description}

Indicates whether the victim is female

Age of the victim

The victim is a farmworker

The victim is an unskilled manual worker

The victim is an employer

The victim is unemployed

Schooling years

criminals had a weapon (knife, gun, etc.)

the victim didn't know the criminal(s)

the victim believes municipal police is corrupt
The victim is a self-employed

Victim's estimation of the monetary value of substracted goods or the money given to criminals (constant Mexican currency of 2018) ${ }^{1}$

victim was accompanied when the crime happened

Categorical variable from 1 to 4 , where 1 reflects the victim totally distrust municipal police and 4 reflects total trust

the victim believes living in her neighborhood is safe

Categorical variable from 1 to 4 , where 1 reflects the victim believes municipal police is totally inefficient and 4 reflects a totally efficient performance
Source

ENVIPE $^{2}$

Feels safe at home The victim feels safe at her home

Feels safe in the The victim feels safe in the street street

Feels safe on public The victim feels safe on public transit (bus, subway, etc.) transit

Police presence

Number of policemen per 100,000 people in the state where the

CNGSPSPE $^{3}$ victim lives

Police corruption Average perceived police corruption in the state where the victim $\mathrm{ENCIG}^{4}$ lives. The scale goes from 1 to 4 , where 1 reflects that an inhabitant believes police is not corrupt and 4 reflects totally corrupt. 
Government effectiveness
Average perceived goverment effectiveness in the state where the

ENCIG victim lives. The average is computed based on opinions of inhabitants that went to goverment offices for some procedure. The individual scale goes from 1 to 4 , where 1 reflects that an inhabitant considers gonverment is not efficient at all for procedures and 4 reflects an inhabitant considers the goverment is totally efficient for procedures.

Population density

Source: Own elaboration.

${ }^{1}$ We adjusted using the values of the Consumer Price Index (IPC) of April in each year (july 2018=100), downloaded from the website of the Mexican Central Bank. ${ }^{2}$ National Survey of Crime Victims and Perceptions of Public Safety. ${ }^{3}$ National Census of State Governments, Public Safety, and Penitentiary Systems. ${ }^{4}$ National Survey on Government Quality and Impact.

${ }^{5}$ Population data come from the conapo and municipal areas are own estimations. ${ }^{6}$ National Population Council.

and for public theft and extortion, we include dummies for the presence of a weapon, an unknown perpetrator, and for whether the victim was accompanied or alone. ${ }^{11}$ For burglaries, we also include dummy perception variables for whether the victim feels safe at home, and for public theft, we include them to indicate whether the victim feels safe in the street and on public transportation. ${ }^{12}$ Table 1 describes all variables included throughout the analysis.

\subsection{Descriptive Statistics}

Table 2 shows descriptive statistics for each of the explanatory factors described above. There are 9,427 burglaries, of which 22 percent were reported to the public prosecutor's office, the highest rate among the crimes analyzed here. The victims who reported these crimes were slightly older, more of ten women, and with a slightly

${ }^{11}$ We include this variable as a proxy for social influence, as in Greenberg and Beach (2004).

${ }^{12}$ We use these variables as a proxy for fear of crime, as in Torrente, Gallo, and Oltra (2017)there are significant differences among countries, both in terms of overall and specific crime-reporting rates. Factors highlighted by the literature that might explain these differences are not entirely satisfactory. There is little comparative research, and most published studies are nation-centred, based on the experience of central and northern European countries, and largely focused on the situational variables related to the criminal incident itself. It is widely assumed that situational variables have a universal explanatory capacity in crime reporting. This article questions this assumption and shows that a number of factors weight differently in explaining national rates. Following a literature review, we identified four groups of causal factors and analysed their explanatory capacity. These are related largely to the incident (rational models. 
Why do mexicans report so little crime? The determinants of crime reporting in Mexico

\section{Table 2. Descriptive Statistics for Reported/ not Reported Crime Types}

\begin{tabular}{|c|c|c|c|c|c|c|c|c|}
\hline \multirow[t]{2}{*}{ Variable } & \multicolumn{2}{|c|}{ Burglary } & \multicolumn{2}{|c|}{ Public theft } & \multicolumn{2}{|c|}{ Extortion } & \multicolumn{2}{|c|}{ Fraud } \\
\hline & Yes & No & Yes & No & Yes & No & Yes & No \\
\hline Female & 0.41 & 0.38 & 0.28 & 0.32 & 0.44 & 0.36 & 0.36 & 0.35 \\
\hline Age & 38.04 & 37.27 & 33.58 & 34.94 & 36.44 & 35.77 & 38.67 & 38.43 \\
\hline Day laborer & 0.02 & 0.05 & 0.02 & 0.03 & 0.05 & 0.05 & 0.01 & 0.03 \\
\hline Employee & 0.69 & 0.66 & 0.78 & 0.75 & 0.67 & 0.62 & 0.71 & 0.67 \\
\hline Self-employed & 0.24 & 0.25 & 0.18 & 0.21 & 0.26 & 0.29 & 0.20 & 0.26 \\
\hline Employer & 0.04 & 0.02 & 0.01 & 0.01 & 0.01 & 0.02 & 0.07 & 0.04 \\
\hline Unemployed & 0.01 & 0.01 & 0.00 & 0.01 & 0.02 & 0.01 & 0.00 & 0.00 \\
\hline Years of education & 12.15 & 10.64 & 11.33 & 10.74 & 10.45 & 11.00 & 13.34 & 13.05 \\
\hline Estimated lost value (MXN) & 46228 & 13139 & 9803 & 2998 & 7183 & 4673 & 44931 & 7769 \\
\hline Weapon present & & & 0.88 & 0.86 & 0.32 & 0.27 & & \\
\hline Unknown perpetrator(s) & & & 0.93 & 0.96 & 0.26 & 0.52 & & \\
\hline Victim accompanied & & & 0.44 & 0.34 & 0.64 & 0.57 & & \\
\hline Present when crime occurred & 0.23 & 0.29 & & & & & & \\
\hline Trust municipal police & 2.05 & 2.06 & 2.04 & 1.99 & 2.02 & 1.99 & 2.06 & 2.00 \\
\hline Believe neighborhood safe & 0.32 & 0.32 & 0.35 & 0.31 & 0.40 & 0.43 & 0.48 & 0.49 \\
\hline Believe municipal police corrupt & 0.81 & 0.82 & 0.86 & 0.87 & 0.83 & 0.84 & 0.85 & 0.85 \\
\hline Municipal police performance & 2.09 & 2.14 & 2.11 & 2.06 & 2.07 & 2.09 & 2.11 & 2.08 \\
\hline Feel safe at home & 0.49 & 0.57 & & & & & & \\
\hline Feel safe in the street & & & 0.11 & 0.09 & & & & \\
\hline Feel safe on public transit & & & 0.13 & 0.10 & & & & \\
\hline Police presence & 191 & 184 & 187 & 147 & 175 & 191 & 198 & 159 \\
\hline Police corruption & 3.53 & 3.53 & 3.56 & 3.58 & 3.51 & 3.53 & 3.52 & 3.53 \\
\hline Government effectiveness & 3.19 & 3.19 & 3.12 & 3.09 & 3.17 & 3.17 & 3.17 & 3.16 \\
\hline Observations & 2072 & 7355 & 870 & 6877 & 1416 & 5622 & 570 & 5544 \\
\hline
\end{tabular}

Source: Own elaboration.

Note. The table shows descriptives statistics for reported (yes) / not reported (no) crimes. 
higher educational level than those who did not report them ${ }^{13}$. Burglaries, where the victim was not present, were more commonly reported, which might be expected since there would be less fear to report in the absence of direct contact with the criminal (see Kääriäinen and Siren 2011) ${ }^{14}$. The estimated value of property lost was notably higher in the reported crimes (see Figure A3), and the victims who reported them felt less safe at home, which perhaps served as a motivation to seek protection by reporting them.

There were 7747 public thefts, of which 11.23 percent were reported. Victims who reported these crimes were more frequently male, unemployed, with a slightly higher educational level. They lost property of significant value and were more commonly accompanied than those who did not report the crime. They also tended to have more trust in the police, a more favorable view of the performance of the police, and a greater feeling of safety. The state governments in which more victims reported these crimes were perceived to be more effective.

The number of crimes of extortion, threats, and assault totaled 7038, of which 20.11 percent were reported. Victims who reported these crimes were more frequently women, and they tended to have lower-level employment, lose property of greater value, be threatened with a weapon, and more frequently know their offenders than those who did not.

Finally, there were 6114 crimes involving fraud, of which 9.32 percent were reported. Victims who reported these crimes lost property of greater value, had greater trust in the police and a slightly better opinion of their performance than those who did not.

\subsection{Model Specification}

For any of the six types of crime described above, we observe a crime $j$ of which an individual $i$ is a victim in the year $t$ and state $s$. Then, the propensity of individual $i$ to report crime $j$ is identified by the following equation:

$$
y_{j i s t}^{*}=\tau_{t}+\lambda_{s}+\beta_{0}+\beta_{1}^{\prime} x_{1 i s t}+\beta_{2}^{\prime} x_{2 j s t}+\beta_{3}^{\prime} x_{3 s t}+\varepsilon_{i s t}
$$

${ }^{13}$ For a comparison of the distributions of age, years of education, and estimated lost value for all crime types and reporting decision see Figures A1, A2, and A3 in the appendix.

${ }^{14}$ Nonetheless, table 2 also shows that reported burglaries where victims were more commonly absent at the crime moment correspond to a higher value lost. Therefore, it might also be that the greater tendency to report might be driven by the higher value lost and not due to a less fear to report in the absence of direct contact with the criminal(s).

Sobre México. Temas de Economía. Nueva Época. 2022. 5(3) 
This latent variable determines the observed outcome through the equation:

$$
y_{j i s t}=\left\{\begin{array}{l}
1 \text { if } y_{j i s t}^{*}>0 \\
0 \text { if } y_{j i s t}^{*}<0
\end{array}\right.
$$

where $y_{j i s t}^{*}$ is a latent variable that reflects the individual's propensity to report crime $j ; \tau_{t}$ are year fixed effects; $\lambda_{s}$ are state fixed effects; $x_{1 i s t}$ are sociodemographic and perception characteristics of individual $i$; $x_{2 j i s t}$ are characteristics of crime $j x_{3 s t} ; \varepsilon_{i s t}$ : are state-level variables of state $s$; and is an error term. Given that an individual $i$ might be the victim of more than one crime, standard errors are clustered at the individual level.

\section{Results and Discussion}

In Table 3, we present the estimations of equation (1) for every crime type. Among the main results for burglaries, we see that years of education is the only sociodemographic factor that explains reporting, contrary to the findings in MacDonald (2001) in which unemployment affects reporting; that is, burglary is not related to the economic cycles. On the other hand, the estimated value of lost property increases the probability of reporting, which is consistent with previous findings in the literature (Zhang, Messner, and Liu 2007; Kääriäinen and Siren 2011; MacDonald 2001; and Greenberg and Beach 2004). The perception that police are corrupt decreases the probability of reporting a burglary, even after controlling for individual trust in police and opinion of police performance. This outcome, which is not found in previous studies, likely reflects victims' belief that police might have links with criminals. This outcome is alarming, given the high perception of police corruption in Mexico. ${ }^{15}$ Finally, none of the community characteristics are significant.

${ }^{15}$ According to Transparency International, 69 percent of the population in Mexico consider the police corrupt. In Colombia and Chile the figures are 42 and 38 percent, respectively (Transparency International, 2019). 
Constantino Carreto — Aurora Ramírez-Álvarez

Table 3. Crime Reporting Factors by Crime Type

VARIABLE

Sociodemographic Variables:

\begin{tabular}{|c|c|c|c|c|}
\hline \multirow[t]{2}{*}{ Female } & $0.0968^{*}$ & $-0.148^{* *}$ & $0.140^{*}$ & 0.0340 \\
\hline & $(0.0544)$ & $(0.0676)$ & $(0.0808)$ & $(0.0751)$ \\
\hline \multirow[t]{2}{*}{ Age } & 0.00773 & $0.0314^{* *}$ & 0.00184 & 0.0103 \\
\hline & $(0.0113)$ & $(0.0157)$ & $(0.0154)$ & $(0.0196)$ \\
\hline \multirow[t]{2}{*}{ Age squared } & $-8.35 e-05$ & $-0.000418^{* *}$ & $9.66 \mathrm{e}-05$ & -0.000154 \\
\hline & $(0.000132)$ & $(0.000202)$ & $(0.000202)$ & $(0.000240)$ \\
\hline \multirow[t]{2}{*}{ Day laborer ${ }^{1}$} & $-0.540^{*}$ & -0.245 & 0.328 & -0.508 \\
\hline & $(0.310)$ & $(0.313)$ & $(0.263)$ & $(0.326)$ \\
\hline \multirow[t]{2}{*}{ Employee } & -0.414 & 0.0306 & $0.569^{* *}$ & -0.219 \\
\hline & $(0.291)$ & $(0.291)$ & $(0.235)$ & $(0.261)$ \\
\hline \multirow[t]{2}{*}{ Self-employed } & -0.416 & -0.0101 & 0.349 & -0.424 \\
\hline & $(0.292)$ & $(0.296)$ & $(0.241)$ & $(0.266)$ \\
\hline \multirow[t]{2}{*}{ Employer } & -0.330 & 0.0404 & 0.0799 & -0.135 \\
\hline & $(0.311)$ & $(0.459)$ & $(0.299)$ & $(0.310)$ \\
\hline \multirow[t]{2}{*}{ Unemployed } & -0.105 & $-0.608^{* * *}$ & $0.457^{*}$ & -0.131 \\
\hline & $(0.216)$ & $(0.218)$ & $(0.234)$ & $(0.310)$ \\
\hline \multirow[t]{2}{*}{ Years of education } & $0.0341^{* * *}$ & $0.0181^{* *}$ & -0.00297 & -0.00373 \\
\hline & $(0.00674)$ & $(0.00850)$ & $(0.00938)$ & $(0.00894)$ \\
\hline \multicolumn{5}{|l|}{ Incident-Specific Variables: } \\
\hline \multirow[t]{2}{*}{ Log of estimated lost value } & $0.143^{* * *}$ & $0.0957^{* * *}$ & $0.0678^{* * *}$ & $0.263^{* * *}$ \\
\hline & $(0.0156)$ & $(0.0205)$ & $(0.00987)$ & $(0.0320)$ \\
\hline \multirow[t]{2}{*}{ Weapon present } & & $0.234^{* * *}$ & 0.122 & \\
\hline & & $(0.0824)$ & $(0.0745)$ & \\
\hline \multirow[t]{2}{*}{ Unknown perpetrator } & & $-0.345^{* *}$ & $-0.499^{* * *}$ & \\
\hline & & $(0.147)$ & $(0.0774)$ & \\
\hline \multirow[t]{2}{*}{ Victim accompanied } & & $0.255^{* * *}$ & $0.151^{* *}$ & \\
\hline & & $(0.0644)$ & $(0.0632)$ & \\
\hline \multirow[t]{2}{*}{ Present when crime occurred } & 0.0844 & & & \\
\hline & $(0.0582)$ & & & \\
\hline
\end{tabular}

\section{Burglaries Thefts Extortion Frauds}

Thefts Extortion Frauds \\ Thefts \\ extortion \\ (a)}


Why do mexicans report so little crime? The determinants of crime reporting in Mexico

Perceptions:

$\begin{array}{lcccc}\text { Trust municipal police } & 0.0118 & 0.0303 & 0.0183 & 0.0918^{*} \\ \text { Believe neighborhood safe } & (0.0361) & (0.0497) & (0.0439) & (0.0549) \\ & 0.0538 & -0.00844 & -0.0876 & -0.133^{* *} \\ \text { Believe municipal police corrupt } & (0.0571) & (0.0694) & (0.0650) & (0.0675) \\ & -0.172^{* *} & 0.0330 & -0.112 & 0.0821 \\ \text { Municipal police performance } & (0.0738) & (0.104) & (0.0892) & (0.107) \\ & -0.0622 & -7.68 \mathrm{e}-06 & -0.0667 & -0.0190 \\ \text { Feel safe in the street } & (0.0405) & (0.0551) & (0.0495) & (0.0555) \\ \text { Feel safe on public transit } & & 0.0364 & & \\ & & (0.0965) & & \\ & & -0.0624 & & \\ & & (0.0729) & & \\ & & & \end{array}$

Feel safe at home

$-0.136^{* *}$

(0.0598)

Community Characteristics:

$\begin{array}{lcccc}\text { Police presence } & 0.000179^{*} & 0.000502^{* * *} & -0.000289^{* *} & 5.32 \mathrm{e}-05 \\ & (0.000108) & (0.000181) & (0.000145) & (0.000172) \\ \text { Log of police corruption } & 1.807 & 0.0855 & -0.652 & -3.830^{* *} \\ & (1.339) & (1.309) & (1.421) & (1.791) \\ \text { Log of bureaucratic efficiency } & 1.249 & 0.802 & 1.844 & -1.337 \\ & (1.453) & (1.412) & (1.847) & (1.942) \\ \text { Constant } & -5.662^{* *} & -3.678 & -3.133 & 2.839 \\ & (2.680) & (2.543) & (3.063) & (3.416) \\ & & & & \\ \text { Observations } & 9,427 & 7,747 & 7,038 & 6,114 \\ \text { Pseudo } \mathrm{R}^{2} & 0.103 & 0.0850 & 0.116 & 0.144\end{array}$

Source: Own elaboration.

Note. Values are coefficients from probit regression. Robust standard errors in parentheses. ${ }^{* * *} \mathrm{p}<0.01,{ }^{* *} \mathrm{p}<0.05,{ }^{*}$ $\mathrm{p}<0.1$. SE adjusted for clusters at the individual level. 1 Omitted labor status category is unpaid worker. All regressions include state and year dummies. Extortion and fraud include crime subtype dummies. 
For public theft, our results show that women are less likely to report than men. This outcome might imply that women are more sensitive to violent crimes like public theft and are therefore more afraid of reporting them. The propensity to report public theft increases non-linearly with age indicating that middle-aged adults are more susceptible to report, compared to young adults or older adults. The finding that unemployment is inversely related to reporting suggests that the relationship between reporting and the economic cycles for burglaries found in MacDonald (2001) does apply to public theft in Mexico.

All the incident-specific variables included in the analysis are significant predictors of the decision to report a public theft. A higher value of property lost, the presence of a weapon and an accompanied victim (a proxy for social influence, i.e., advice) increase the propensity to report a public theft, while unknown perpetrator decreases it. The positive effect of lost value is consistent with Zhang, Messner, and Liu (2007), Kääriäinen and Siren (2011), and Greenberg and Beach (2004). It likely reflects the expectation that with the reporting of the crime and possible capture of the perpetrator, the victim might recover some of the money or goods lost in the theft. Weapon presence implies a more violent and serious crime, thus increasing the urgency to report. The negative effect of unknown perpetrator implies that victims are more inclined to report if they know the robber, possibly due to a higher expectation of capture. On the other hand, none of the belief and perception variables showed a significant relationship with reporting, suggesting that in our model for theft, the characteristics of the incident are the most important factors influencing reporting. Among community variables, only police presence shows a significant relationship. This might be the case because a higher density of police makes it easier to call them and then report the crime to the public prosecutor's office.

For the third group of crimes, extortions (which includes extortion, threats, and assault), we see in Table 3 that in our model, sociodemographic characteristics do not seem to be related to reporting, where only one of the labor statuses (employee) is significant. Likewise, perceptions and community characteristics do not help explain reporting. On the contrary, and similarly to thefts, incident characteristics are the most relevant drivers of the decision to report (Figure 2 illustrates this similarity). Nonetheless, in most cases, the effects for thefts tend to be more considerable: for instance, the coefficient of victim accompanied is greater for thefts, which might be explained by the victim's greater exposure to advice given that the crime occurs in the street or the public transportation. 
Figure 2. Coefficients of incident variables

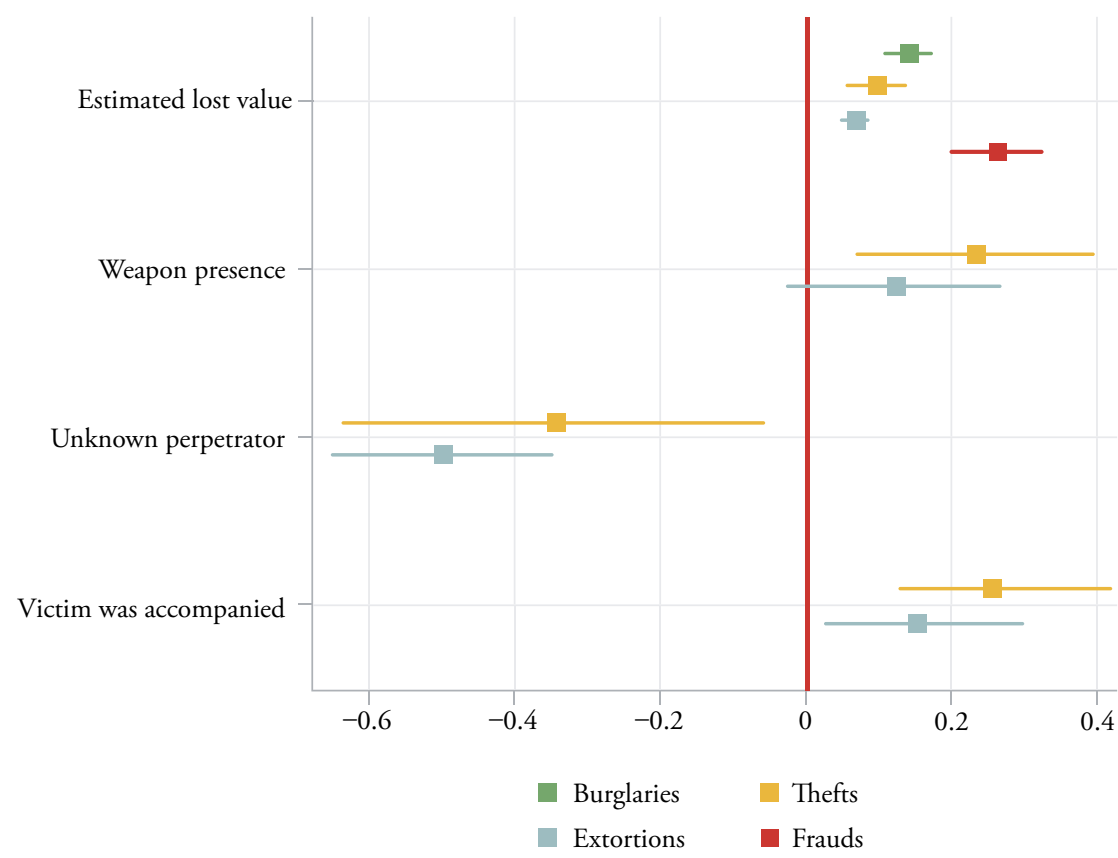

Source: Own elaboration.

Note: The plot shows the coefficients and 95\% confidence intervals of the incident-specific variables from the regression in Table 3.

For frauds, Table 3 shows that sociodemographic characteristics do not seem to be related to reporting, while lost value is not only a significant predictor as in the other crime types, but also it impacts fraud reporting the most, compared to the other crime types (see Figure 2). This result shows that incidental characteristics, which describe the crime or economic loss, are the most consistent predictors of reporting and are a common feature for a broad group of crimes. In addition, this impact depends on the level of the variable. As shown in Figure 3 , the range of the magnitude and the slope of the impact of the estimated lost value on the probability of reporting differs among crime types, where fraud presents the widest range and the fastest increases. This last fact suggests that fraud victims are the most susceptible to reporting the crime when the lost value gets larger. 
Figure 3. Effect of the estimated lost value on the probability of reporting

BURGLARIES

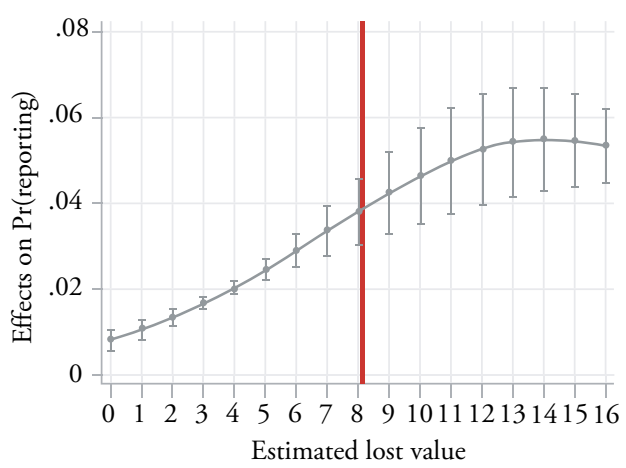

EXTORTIONS

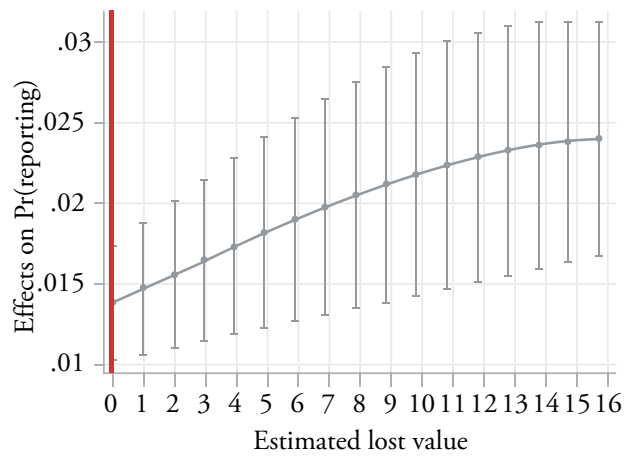

THEFTS

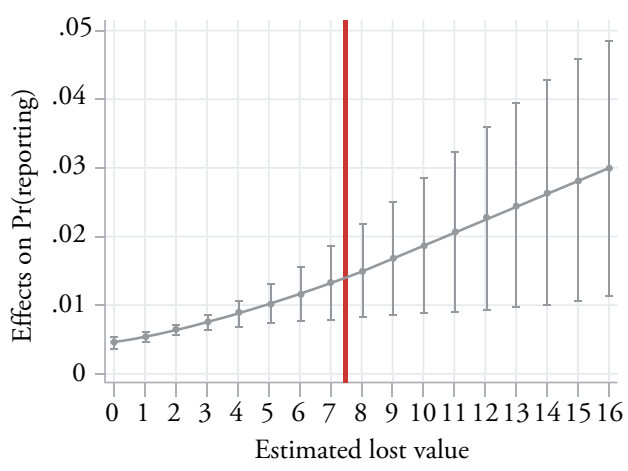

FRAUDS

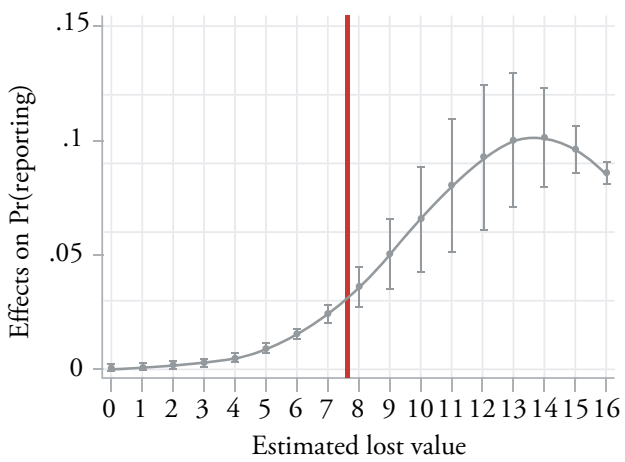

Source: Own elaboration.

Note: The panels show the effects and $95 \%$ CI of the estimated lost value on the probability of reporting, for different values of the logarithm of the estimated lost values. The vertical line indicates the value of the logarithm that corresponds to the median of the estimated lost value in constant Mexican pesos for every crime type.

Moreover, for frauds, the perception of a safe neighborhood decreases the probability of reporting fraud, which suggests that at the moment of the interview, up to a year after suffering the fraud, those who reported fraud tended to perceive that their neighborhood was unsafe more than those who did not report it. The feeling of insecurity at the time of the interview might reflect part of the victim's feeling of insecurity just after the crime. ${ }^{16}$ Finally, a greater perception of police corruption at the community level decreases the probability to report.

${ }^{16}$ Note that the magnitude of the effect might have been lessened by reverse causality, since reporting the crime likely decreased the feeling of insecurity. 
At the same time, the individual perception of corruption has no significant relationship to reporting, so individual corruption perceptions might be strongly shaped by the general perceived corruption in the community.

\subsection{Robustness Checks}

A couple of works point out that victimization is not a random condition and that some sociodemographic characteristics might influence both the probabilities of victimization and reporting the crime (Osborn, Trickett, and Elder 1992; Trickett, Osborn, and Ellingworth 1995; Fajnzylber et al. 2000; Barslund et al. 2007). In this scenario, we would have a sample selection problem (Greene, 2012) and we would need to use a bivariate probit, otherwise, estimations by a simple probit model might be biased. To exclude this possibility, we compute a Wald test under the null hypothesis of non-correlation of the errors between the equations that describe victimization and reporting. For this test, we use different variables termed instruments, which we verified explained the victimization condition but were non-statistically significant in the estimation of the reporting equation. In Table A1 in the appendix, we show the result of the test when using drug consumption as the instrument ${ }^{17}$. The results indicate that we cannot reject the null hypothesis of non-correlation, which suggests that, in our case, simple probit estimations are not biased and it is not necessary to use a bivariate probit. For comparison purposes, in Table A 2 we show the estimations of equation 1 corrected by sample selection. As shown, our main results are robust to the use of a bivariate probit.

\section{Conclusions}

In this paper, we analyze the factors that explain crime reporting in the context of Mexico, a developing and highly violent country, for the years 2011, 2013, 2015, and 2017, with separate analyses for burglaries, public thefts, extortions, and frauds. The main findings show that the factors that explain reporting vary across crime types, but the group of variables that describe the incident (e.g., estimated value of property lost, if the victim was accompanied, etc.) are the most

${ }_{17}$ As the other individual characteristics, the data for this variable comes from the ENviPE. This variable corresponds to the question "Is there drug consumption in your neighborhood?”. 
consistent in explaining reporting across all types, while perception variables and community characteristics depend more on the specific types.

Most of our results for socioeconomic characteristics are consistent with previous findings for other countries. The same, in general, can be said for the incidentspecific variables. However, our results also indicate that victims' perceptions of the corruption of municipal police decrease the likelihood that they will report burglaries, a result not found in other studies. Besides, for frauds, the perception of police corruption on the community level also decreases reporting.

The fact that incident-specific variables such as the estimated value of property lost increases reporting independently of the crime type under analysis suggests that victims might be doing a cost-benefit analysis when deciding to report, where one of the benefits of reporting is the potential recovery of the property lost, while the cost represents the hurdles of reporting. Policies that reduce these hurdles such as reporting times could help decrease underreporting.

Although very challenging, there are also possibilities for interventions at the level of perception and community characteristics to increase crime reporting and reduce impunity. For example, public policy that is geared towards countering corruption in institutions of public security such as the police, apart from its own merits, could also increase crime reporting and reduce impunity.

\section{References}

Allen, W. D. (2007). The Reporting and Underreporting of Rape. Southern Economic Journal, 73(3), 623-641. https://doi.org/10.2307/20111915

Barslund, M., Rand, J., Tarp, F., \& Chiconela, J. (2007). Understanding Victimization: The Case of Mozambique. World Development, 35(7), 12371258.https://doi.org/https://doi.org/10.1016/j.worlddev.2006.09.018

Beittel, J. S. (2015). Mexico: Organized crime and drug trafficking organizations. Congressional Research Service, 3.

Benavente, J. M., \& Cortés, E. (2006). Delitos y sus denuncias. La cifra negra de la criminalidad en Chile y sus determinantes. Serie Documentos de Trabajo, 228(October), 26.

ENVipe. (2019). Encuesta Nacional de Victimización y Percepción sobre Seguridad Pública 2019. Principales resultados. 
Fajnzylber, P., Lederman, D., Loayza, N., Reuter, P., Roman, J., \& Gaviria, A. (2000). Crime and Victimization: An Economic Perspective. Economía, 1(1), 219-302.

Goudriaan, H., \& Nieuwbeerta, P. (2007). Contextual determinants of juveniles' willingness to report crimes. Journal of Experimental Criminology, 3(2), 89-111. https://doi.org/10.1007/s11292-007-9030-4

Greenberg, M. S., \& Beach, S. R. (2004). Property Crime Victims’ Decision to Notify the Police: Social, Cognitive, and Affective Determinants. Law and Human Behavior, 28(2), 177-186. https://doi.org/10.1023/ B:LAHU.0000022321.19983.ea

Greenberg, M. S., Wilson, C. E., Ruback, R. B., \& Mills, M. K. (1979). Social and Emotional Determinants of Victim Crime Reporting. Social Psychology Quarterly, 42(4), 364-372. https://doi.org/10.2307/3033806 Greene, W. W. H. . (2012). Econometric analysis 7th Ed. In Prentice Hall. Guzy, N., \& Hirtenlehner, H. (2015). Trust in the German Police: Determinants and Consequences for Reporting Behavior BT - Trust and Legitimacy in Criminal Justice: European Perspectives (G. Meško \& J. Tankebe (eds.); pp. 203-229). Springer International Publishing. https://doi. org/10.1007/978-3-319-09813-5_10

Kääriäinen, J., \& Siren, R. (2011). Trust in the police, generalized trust and reporting crime. European Journal of Criminology - EUR J CRIMINOL, 8, 65-81. https://doi.org/10.1177/1477370810376562

Kääriäinen, J., \& Sirén, R. (2010). Trust in the police, generalized trust and reporting crime. European Journal of Criminology, 8(1), 65-81. https://doi.org/10.1177/1477370810376562

Lastiri, D. (2019, December). Van 7 mil 942 víctimas de Extorsión durante 2019. El Universal.

MacDonald, Z. (2001). Revisiting the Dark Figure: A Microeconometric Analysis of the Under-reporting of Property Crime and Its Implications. The British Journal of Criminology, 41(1), 127-149. https://doi. org/10.1093/bjc/41.1.127

Osborn, D. R., Trickett, A., \& Elder, R. (1992). Area characteristics and regional variates as determinants of area property crime levels. Journal of Quantitative Criminology, 8(3), 265-285.

Pariona, A. (2018). Murder Rate By Country. Retrieved from https://www. worldatlas.com/articles/murder-rates-by-country.html 
Robles, G., Calderón, G., \& Magaloni, B. (2013). The economic consequences of drug trafficking violence in Mexico. Poverty and Governance Series Working Paper, Stanford University.

Sidebottom, A. (2014). On the Correlates of Reporting Assault to the Police in Malawi. The British Journal of Criminology, 55(2), 381-398. https:// doi.org/10.1093/bjc/azu083

Skogan, W. G. (1976). CITIZEN REPORTING OF CRIME Some National Panel Data. Criminology, 13(4), 535-549. https://doi. org/10.1111/j.1745-9125.1976.tb00685.x

Tarling, R., \& Morris, K. (2010). Reporting Crime to the Police. The British Journal of Criminology, 50(3), 474-490. https://doi.org/10.1093/ bjc/azq011

Torrente, D., Gallo, P., \& Oltra, C. (2017). Comparing crime reporting factors in EU countries. European Journal on Criminal Policy and Research, 23(2), 153-174. https://doi.org/10.1007/s10610-016-9310-5

Transparency International. (2019). Global Corruption Barometer. Latin America \& the Caribbean 2019.

Trickett, A., Osborn, D. R., \& Ellingworth, D. (1995). Property crime victimisation: the roles of individual and area influences. International Review of Victimology, 3(4), 273-295.

Villanueva, D. (2019, September). En 2018, las pérdidas por robos, asaltos o extorsiones representaron 286 mil mdp. La Jornada, 5.

Yun, I., \& Mueller, D. (2011). A study of the determinants of reporting crime to the police among Chinese immigrants. International Journal of Comparative and Applied Criminal Justice, 35(1), 53-71. https://doi. org/10.1080/01924036.2011.535697

Zhang, L., Messner, S. F., \& Liu, J. (2007). An exploration of the determinants of reporting crime to the police in the city of Tianjin, China. Criminology, 45(4), 959-984. https://doi.org/10.1111/j.1745-9125.2007.00093.x 
Why do mexicans report so little crime? The determinants of crime reporting in Mexico

\section{APPENDIX}

Table A1. Wald tests to verify sample selection problem

$\begin{array}{cccc}\text { Burglaries } & \text { Thefts } & \text { Extortions } & \text { Frauds } \\ 0.321 & -0.209 & 0.283 & 0.809 \\ 0.20 & 0.31 & 0.09 & 0.07\end{array}$

In the table are shown: $i)$ the estimators of the correlations between the selection and reporting equations in a sample selection framework (upper row) and; ii) the corresponding p-values (lower row). The null hypothesis is that the correlation equals zero.

\section{Table A2. Crime Reporting Factors Corrected for Sample Selection Bias}

\section{VARIABLE}

Sociodemographic Variables:

Female

Age

Age squared

Day laborer ${ }^{1}$

Employee

Self-employed

Unemployed

Years of education
Employer

\section{Burglary}

Theft

Extortion

0.118

$-0.0711$

$\begin{array}{cccc}0.0804 & -0.114 & 0.118 & -0.0711 \\ (0.0525) & (0.0764) & (0.0761) & (0.0571)\end{array}$

$$
0.00852
$$

$0.0340^{* *}$

0.00405

$0.0286^{*}$

$$
(0.0107)
$$

(0.0153)

(0.0148)

(0.0163)

$\begin{array}{cc}-0.000108 & -0.000420^{* *} \\ (0.000124) & (0.000200)\end{array}$

$3.59 \mathrm{e}-05$

$-0.000376^{*}$

$$
\text { (0.000124) }
$$

(0.000200)

(0.000196)

(0.000200)

$\begin{array}{cccc}-0.528^{*} & -0.206 & 0.329 & -0.444^{*} \\ (0.306) & (0.311) & (0.250) & (0.237)\end{array}$

$$
-0.338
$$

$-0.0249$

$0.605^{* * *}$

$-0.0390$

$$
\text { (0.294) }
$$

(0.295)

(0.223)

(0.194)

$$
-0.325
$$

$-0.0445$

$0.432^{*}$

$-0.110$

(0.301)

(0.294)

(0.230)

(0.216)

$$
-0.190
$$

0.0183

0.187

0.285

$$
\text { (0.325) }
$$

(0.452)

(0.291)

(0.240)

$$
-0.0470
$$

$-0.652^{* * *}$

$0.515^{* *}$

$-0.174$

$$
\text { (0.206) }
$$

$(0.222)$

$(0.223)$

$(0.224)$

$\begin{array}{lc}0.0415^{* * *} & 0.0125 \\ (0.00877) & (0.00950)\end{array}$

0.00582

$0.0523^{* * *}$

Incident-Specific Variables:

Log of estimated lost value

$\begin{array}{cccc}0.136^{* * *} & 0.0948^{* * *} & 0.0655^{* * *} & 0.194^{* * *} \\ (0.0187) & (0.0200) & (0.00957) & (0.0360)\end{array}$




\section{Constantino Carreto = Aurora Ramírez-Álvarez}

\begin{tabular}{|c|c|c|c|}
\hline Weapon present & & $0.228^{* * *}$ & $0.120^{*}$ \\
\hline & & $(0.0809)$ & $(0.0721)$ \\
\hline unknown perpetrator & & $-0.335^{* *}$ & $-0.490^{* * *}$ \\
\hline & & $(0.148)$ & $(0.0774)$ \\
\hline Victim accompanied & & $0.250^{* * *}$ & $0.147^{* *}$ \\
\hline & & $(0.0663)$ & $(0.0617)$ \\
\hline Present when crime occurred & 0.0867 & & \\
\hline & & & \\
\hline
\end{tabular}

\section{Perceptions:}

Trust municipal police

0.0281

0.0192

0.0651

(1)

Believes neighborhood safe

(0.0344)

$(0.0484)$

(0.0420)

(0.0399)

Believes municipal police corrupt

$0.0370 \quad-0.000143$

$-0.101$

$-0.134^{* * *}$

$(0.0589)$

(0.0696)

(0.0631)

(0.0476)

\section{$-0.163^{* *}$}

0.0287

$-0.102$

0.0688

$(0.0737)$

(0.102)

(0.0856)

(0.0776)

$$
-0.0643^{*}
$$

0.00305

$-0.0685$

$-0.00824$

(0.0386)

(0.0546)

(0.0476)

$(0.0393)$

Feels safe in the street

$$
0.0383
$$

Feels safe on public transit

$$
-0.0562
$$

(0.0714)

Feels safe at home

$-0.133^{* *}$

(0.0573)

\section{Community Characteristics:}

\begin{tabular}{lcccc} 
Police presence & 0.000168 & $0.000498^{* * *}$ & $-0.000276^{* *}$ & $3.58 \mathrm{e}-05$ \\
& $(0.000102)$ & $(0.000179)$ & $(0.000137)$ & $(0.000121)$ \\
Log of police corruption & 1.610 & 0.115 & -0.621 & $-2.807^{*}$ \\
& $(1.293)$ & $(1.286)$ & $(1.369)$ & $(1.449)$ \\
\hline Log of government effectiveness & 1.260 & 0.739 & 1.794 & -1.032 \\
Constant & $(1.390)$ & $(1.390)$ & $(1.774)$ & $(1.425)$ \\
& $-6.231^{* *}$ & -3.021 & -3.344 & -1.092 \\
& $(2.558)$ & $(2.604)$ & $(2.992)$ & $(2.944)$ \\
Observations & & & & \\
& 269,005 & 267,325 & 266,616 & 265,692
\end{tabular}

Values are coefficients from Heckman-probit regression. Robust standard errors in parentheses. ${ }^{* * *} \mathrm{p}<0.01,{ }^{* *}$ $\mathrm{p}<0.05,{ }^{*} \mathrm{p}<0.1$. SE adjusted for clusters at the individual level. ${ }^{1}$ Omitted labor status category is unpaid worker. All regressions include state and year dummies. Extortion and fraud include crime subtype dummies. The instrument used in the selection equation is whether in the neighborhood there is drug consumption. 
Why do mexicans report so little crime? The determinants of crime reporting in Mexico

Figure A1. Distribution of age by crime type and reporting decision

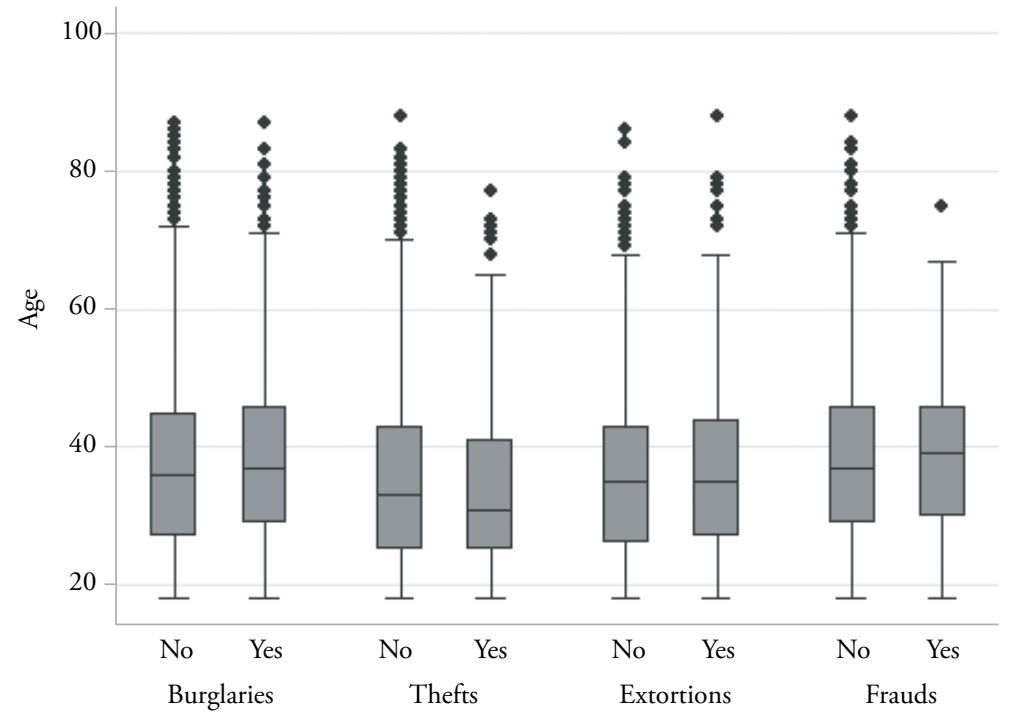

Note: The figure shows the distribution of age by crime type and yes/no decision to report.

Figure A2. Distribution of years of education by crime type and reporting decision

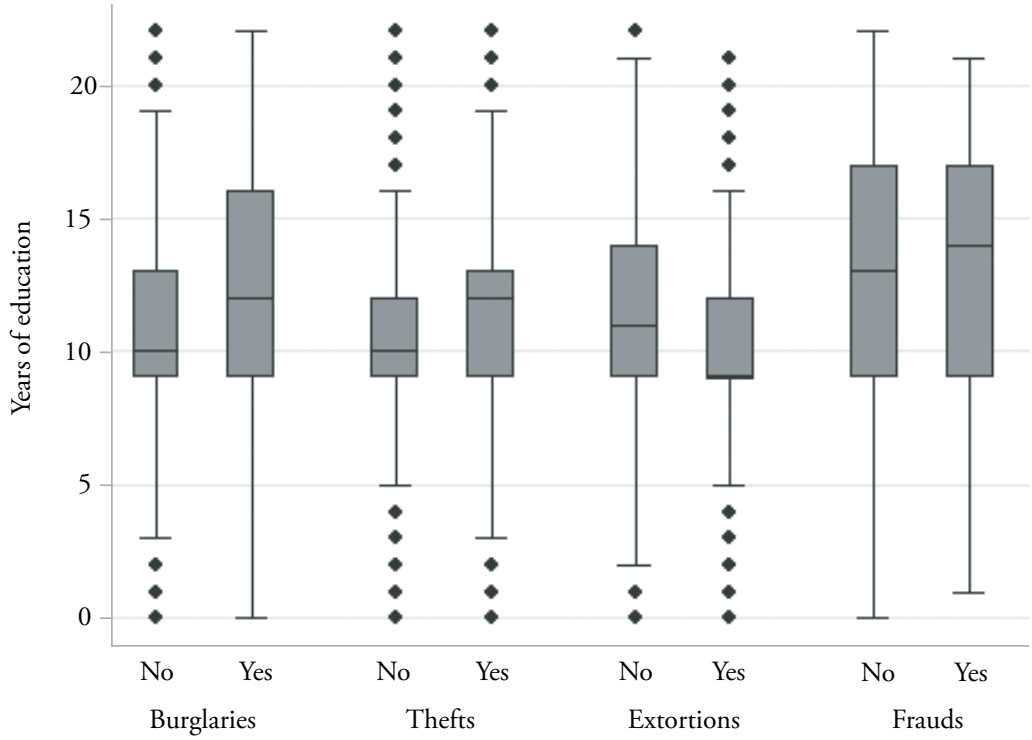

Note: The figure shows the distribution of years of education by crime type and yes/no decision to report. 
Constantino Carreto • Aurora Ramírez-Álvarez

Figure A3. Distribution of estimated lost value by crime type and reporting decision

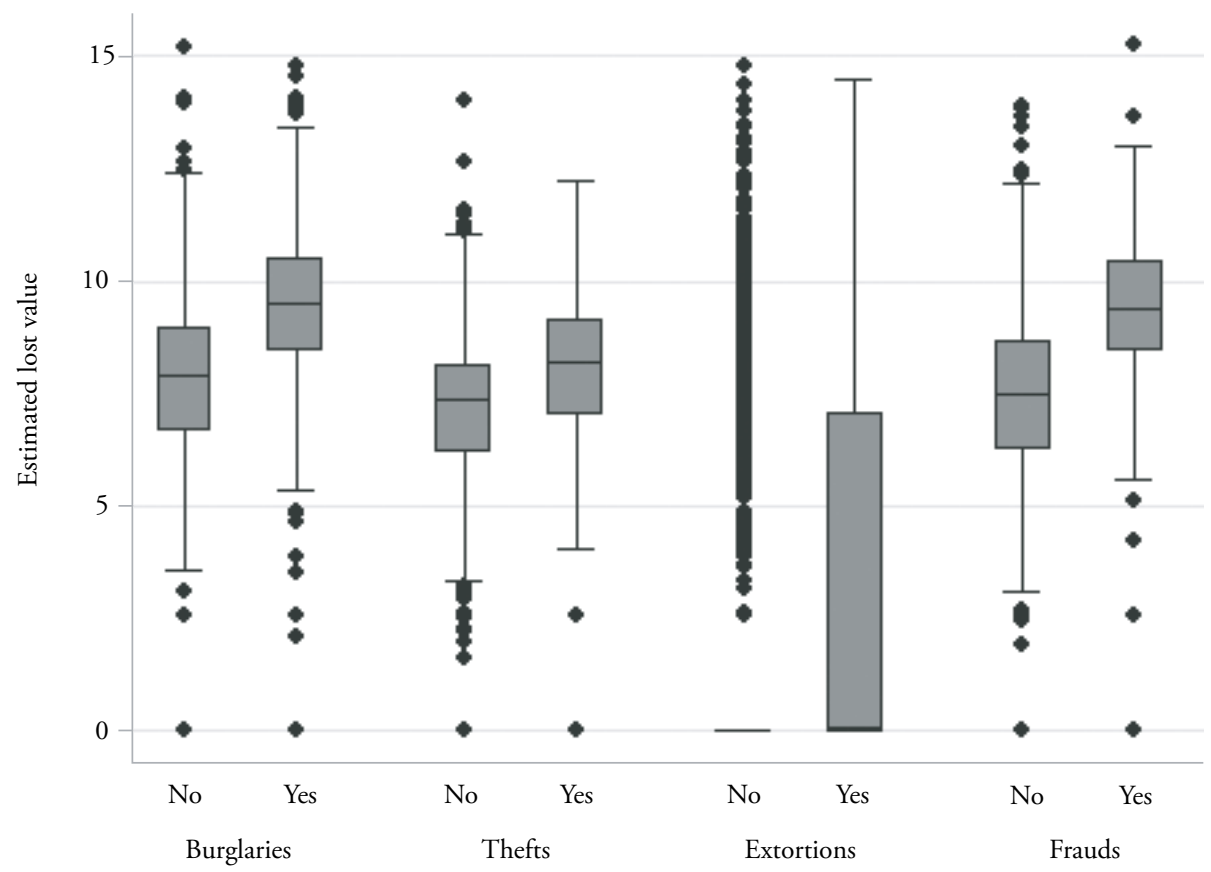

Note: The figure shows the distribution of the logarithm of the estimated lost value by crime type and yes/no decision to rebort. 